\title{
Kepadatan Cacing Tanah pada Lahan Pertanian Tomat Terpapar Pestisida di Desa Ampreng, Kecamatan Langowan Barat - Provinsi Sulawesi Utara (Earthworm Density in Tomato Farming Exposed to Pesticides at Ampreng Village, Langowan Barat Sub District - North Sulawesi Province)
}

\author{
Yulita Tribrata ${ }^{2}$ ), Ratna Siahaan ${ }^{1 *}$ ), Johanis J. Pelealu ${ }^{1}$ ), Susan M. Mambu ${ }^{1}$ ) \\ 1) Jurusan Biologi FMIPA Universitas Sam Ratulangi \\ ${ }^{2)}$ Alumni Jurusan Biologi FMIPA Universitas Sam Ratulangi \\ *Email korespondensi: ratna245_siahaan@yahoo.com
}

\begin{abstract}
Abstrak
Penggunaan pestisida dimaksudkan untuk mempertahankan produksi pertnaian tomat namun hal ini dapat mempengaruhi kepadatan cacing tanah. Penelitan bertujuan menganalisis kepadatan cacing tanah pada lahan pertanian tomat terpapar pestisida di Desa Ampreng, Kecamatan Langowan Barat - Provinsi Sulawesi Utara. Hasil menunjukkan bahwa di lahan pertanian ada dua jenis cacing tanah (Pontoscolex sp. dan Amynthas sp.) dan di lahan pekarangan ada empat jenis (Pontoscolex sp., Amynthas sp., Pheretima sp. dan Perionyx sp). Kepadatan relatif cacing tanah di lahan pertanian yaitu Pontoscolex sp. (66, $49 \%$ ) dan Amynthas sp. (33,51\%) dan pekarangan yaitu Pontoscolex sp. (68, 10\%), Amynthas sp. $(29,31 \%)$, Pheretima sp. (1,72 \%) dan Perionyx sp. (0,86\%). Kepadatan relatif cacing tanah yang lebih rendah di lahan pertanian dibandingkan lahan pekarangan dapat disebabkan oleh residu pestisida mankozeb $(0,035 \mathrm{mg} / \mathrm{kg})$ dan propineb $(0,014 \mathrm{mg} / \mathrm{kg})$. Faktor lain yang turut mempengaruhi yaitu serasah yang lebih sedikit di lahan pertanian tomat dibandingkan di lahan pertanian.

Kata kunci: cacing tanah, kepadatan relatif, pestisida, tomat, Sulawesi Utara
\end{abstract}

\begin{abstract}
The application of pesticides is intended to maintain the production of tomato however this may affect the density of earthworms. The aim of research was to analyze the density of earthworms in tomato farming applied pesticide at Ampreng Village, Langowan West Sub-District - North Sulawesi. The results showed that earthworms in the tomato farming were two taxa i.e Pontoscolex sp.and Amynthas $s p$ and in the front yards were four taxa i.e. Pontoscolex sp Amynthas sp., Pheretima $s p$. and Perionyx sp). The relative density of earthworms in tomato farming were Pontoscolex sp (66, 49\%) and Amynthas sp (33.51\%) and front yards were Pontoscolex sp (68, 10\%), Amynthas sp (29.31\%), Pheretima sp (1, 72\%) and Perionyx $s p(0.86 \%)$. The relative density of earthworms in tomato farming was lower than front yards caused by residue of mancozeb $(0.035 \mathrm{mg} / \mathrm{kg})$ and propineb $(0,014$ $\mathrm{mg} / \mathrm{kg}$ ) and the litter factor. Tomato farming have smaller litter than front yard that reduced the density of earthworm.

Keywords: earthworm, relative density, pesticide, tomatoes, North Sulawesi
\end{abstract}




\section{JURNAL BIOSLOGOS, FEBRUARI 2015, VOL. 5 NOMOR 1}

\section{PENDAHULUAN}

Pertumbuhan penduduk dunia termasuk di Indonesia yang sangat cepat telah menimbulkan kebutuhan akan ketersediaan dan keamanan pangan. Salah satu upaya meningkatkan hasil pertanian yaitu dengan penggunaan pestisida untuk menekan pertumbuhan hama dan penyakit. Namun, penggunaan pestisida juga membahayakan organisma non target seperti cacing tanah yang memiliki fugsi ekologis yag penting. Cacing tanah adalah spesies kunci dalam merombak senyawa organik tumbuhan. Kehadiran cacing tanah di lahan pertanian dapat menjadi bioindikator kerusakan lahan pertanian atau menjadi biomarker untuk menguji pencemaran lingkungan akibat bahan kimia (Faheem \& Khan, 2010).

Penggunaan pestisida untuk meningkatkan produksi tanaman tomat telah cukup lama dilakukan petani di Kecamatan Langowan Barat. Efek pestisida terhadap kepadatan cacing tanah belum pernah dilaporkan. Penelitian ini bertujuan untuk menganalisis kepadatan cacing tanah pada lahan pertanian terpapar pestisida di Desa Ampreng, Kecamatan Langowan Barat-Provinsi Sulawesi Utara.

\section{METODE}

Penelitian dilaksanakan selama 4 bulan dari Mei hingga Agustus 2014. pada lima (5) lahan pertanian tanaman tomat pengguna pestisida dan tiga (3) lahan pekarangan tanpa penggunaan pestisida di Desa Ampreng, Kecamatan Langowan Barat - Provinsi Sulawesi Utara. Pengukuran residu pestisida di tanah berasal dari tanah komposit di lahan pertanian tomat dilakukan di Laboratorium Residu Bahan Argokimia, Bogor - Jawa Barat.
Cacing tanah diambil dari dua lubang galian tanah berukuran masing-masing $18 \times 18 \times 30 \mathrm{~cm}^{3}$ pada tiap subpetak yang telah ditentukan dengan metode sortir tangan (hand sorting). Cacing tanah lalu diindentifikasi di Laboratorium Ekologi FMIPA UNSRAT dan diawetkan dengan formalin $4 \%$ Ciri utama untuk identifikasi berdasarkan ciri-ciri morfologi luar yaitu posisi seta, letak klitelum, bentuk klitelum, prostomium dan pori jantan. Analisis data cacing tanah dilakukan secara deskriptif. Kepadatan cacing tanah di tiap subpetak dihitung berdasar rumus Krebs (1972) yaitu kepadatan = N/V (N: banyaknya individu tiap jenis; volume tanah galian $2 \times 18 \times 18 \times 30$ $\mathrm{cm} 3$ ). Kepadatan relatif dari Suin (2012) yaitu $\mathrm{KR}=\mathrm{K} / \mathrm{jumlah} \mathrm{K} \times 100 \%$ (K: Kepadatan semua jenis)

\section{HASIL DAN PEMBAHASAN}

Petani tomat di Desa Ampreng menggunakan pestisida dalam mengendalikan hama dan penyakit. Tomat ditanam secara monokultur tanpa tanaman sela. Pestisida yang digunakan petani yaitu Insektisida organofosfat profenofos dan fungisida karbamat propineb.

Cacing tanah yang ditemukan di Desa Ampreng termasuk ke dalam Famili Glossoscolecidae dan Megascolecidae. Kekayaan jenis cacing tanah yang ditemukan sebanyak 4 jenis yaitu Pontoscolex sp., Amynthas sp., Pheretima sp., dan Perionyx sp. Keempat jenis cacing tanah tersebut ditemukan di lahan pekarangan namun hanya hanya Pontoscolex sp. dan Amynthas sp ditemukan di pertanian tomat.

Ketidakhadiran cacing tanah Pheretima sp. dan Perionyx sp di pertanian tomt dapat disebabkan oleh faktor serasah organik yang merupakan sumber makanan bagi 
cacing tanah epigeik. Pheretima sp. dan Perionyx sp adalah cacing tanah epigeik yang hidup di permukaan tanah dan memakan serasah atau tumpukan bahan organik (Dominguez \& Edwards, 2011) sehingga tidak ditemukan pada lahan pertanian

Kepadatan relatif (KR) cacing tanah di kedua lahan penelitian berbeda-beda. Cacing tanah jenis Pheretima sp. dan Perionyx sp. memiliki KR yang paling rendah dari 4 jenis cacing tanah yang ditemukan di lahan pekarangan. Nilai KR Pheretima sp yaitu $1,72 \%$ dan Perionyx sp yaitu $0,86 \%$. Sedangkan, cacing tanah jenis Pontoscolex sp memiliki nilai KR tertinggi pada kedua lokasi penelitian yaitu $66,49 \%$ di lahan pertanian dan $68,10 \%$ di lahan pekarangan. Cacing tanah jenis Amynthas sp. memilki KR tertingi kedua setelah cacing tanah Pontoscolex sp. yaitu $33,51 \%$ di lahan pertanian dan $29,31 \%$ di lahan pekarangan. Secara keseluruhan, nilai KR cacing tanah di lahan pertanian tanaman tomat yang menggunakan pestisida lebih rendah dibandingkan dengan lahan pekarangan.

Setiap jenis cacing tanah memiliki toleransi yang berbeda-beda pada kondisi lingkungannya (Hanafiah et al., 2010). Jika kondisi lingkungan sesuai dengan cacing tanah maka semakin meningkat kepadatan cacing tanah. Kepadatan relatif (KR) cacing tanah yang lebih rendah di lahan pertanian dapat disebabkan oleh adanya residu pestisida di tanah lahan pertanian. Hasil uji residu pestisida di tanah lahan pertanian tomat yang dilakukan di Desa Ampreng menunjukkan adanya residu dari golongan ditiokarbamat yaitu mankozeb sebesar $0,035 \mathrm{mg} / \mathrm{kg}$ dan profineb sebesar $0,014 \mathrm{mg} / \mathrm{kg}$. Residu pestisida dari golongan organofosfat yang memiliki bahan aktif profenosfos masih di bawah limit deteksi
$(0,0101 \mathrm{mg} / \mathrm{kg}) \quad$ (Yulipriyanto, 2010). Selain itu, ketidakhadiran kedua cacing tanah epigeik ini dapat disebabkan adanya pestisida di tanah yang dapat mempengaruhi aktivitas cacing tanah terutama cacing tanah epigeik (Pelosi et al., 2013).

Petani di Desa Ampreng umumnya menggunakan insektisida yang mengandung organofosfat dan fungisida yang mengandung karbamat. Pelosi et al. (2013) menyatakan bahwa insektisida memberikan efek negatif terhadap cacing tanah. Pestisida organofosfat dan karbamat merupakan pestisida toksik bagi cacing tanah (Hanafiah et al., 2010). Pestisida dari jenis insektisida dan fungisida sangat beracun terhadap kelangsungan hidup dan reproduksi cacing tanah (Pelosi et al., 2014). Pengurangan aplikasi pestisida pada lahan pertanian dapat meningkatkan kepadatan populasi cacing (Pelosi et al., 2013).

Konsentrasi residu pestisida mankozeb sebesar $0,035 \mathrm{mg} / \mathrm{kg}$ dan profineb $0,014 \mathrm{mg} / \mathrm{kg}$ lebih rendah dari penggunaan pestisida yang dilakukan Marlinda et al. (2013) tentang pengaruh pestisida terhadap fekunditas dan daya tetas cacing tanah. Berdasarkan hal ini, cacing tanah pada lahan pertanian yang terpapar oleh pestisida masih dapat mentolerir pengaruh pestisida yang terjadi pada lahan tersebut. Rendahnya kepadatan cacing tanah pada lahan pertanian bukan hanya disebabkan oleh adanya residu pestisida tetapi juga oleh rendahnya serasah tumbuhan. Berbeda dengan lahan pertanian, pada lahan pekarangan terdapat berbagai jenis tumbuhan hidup yang akan menghasilkan berbagai serasah, yang sangat baik bagi organisme tanah termasuk cacing tanah. Serasah yang beragam di lahan pekarangan turut 
4 JURNAL BIOSLOGOS, FEBRUARI 2015, VOL. 5 NOMOR 1

mendukung bagi kehidupan cacing tanah bertipe epigeik. Hal ini terbukti dengan ditemukannya cacing tanah jenis Pheretima sp. dan Peryonix sp. yang termasuk cacing epigeik di lahan pekarangan tetapi tidak ditemukan di lahan pertanian tomat.

\section{KESIMPULAN}

Kelimpahan relatif $(K R)$ cacing tanah pada lahan pertanian sebesar $66.49 \%$ (Pontoscolex sp) dan $33.51 \%$ (Amynthas sp). KR cacing tanah pada lahan pekarangan yaitu $68.10 \%$ (Pontoscolex sp), Amynthas sp (29.31\%), Pheretima sp (1.72\%) dan Perionyx sp.(29.31\%). Kepadatan cacing tanah pada penelitian ini dapat dipengaruhi oleh penggunaan pestisida dan banyaknya serasah. Lahan pertanian tomat di Desa Ampreng ditanam secara monokultur sehingga serasah pada lahan pertanian lebih rendah dari lahan pekarangan.

\section{DAFTAR PUSTAKA}

Dominguez J, Edwards CA. 2011. Biology and Ecology of Earthworm Species Used for Vermicomposting. Dalam: Edwars CA, Arancon NQ, Sherman RL. Vermiculture Technology: Earthworm, Organic Wastes and Environmental Management. Taylor and Francis Group. Boca Raton. pp: $27-40$

Faheem M, Khan MF. 2010. Toxicity of Imidacloprid (Nicotinoid) Against Earthworm, Pheretima Posthuma with Reference to its Effects on Protein. J. Basic \& Applied Sciences. 6 (1): 55-62

Hanafiah KA, Napoleon A, Ghofar N. 2010. Biologi Tanah. Rajawali Pers. Jakarta

Krebs CJ. 1972. Ecology. Institute of Animal Resource Ecology.
Harpers and Row Publishers. New York

Marlinda T, Nurhadi, Widiana R. 2013. Pengaruh Insektisida Profenofos terhadap Fekunditas dan Daya Tetas Telur Cacing Tanah (Lumbricus rubellus).http://download.portalg aruda.org/article.php?article $=18$ 2810\&val=6308\&title [20 Desember 2014]

Pelosi C, Toutous L, Chiron F, Dubs $F$, Hedde $M$, Muratet $A$, Ponge J.-F, Salmon S, Makowski D. 2013. Reduction of Pesticide Use Can Increase Earthworm Populations in Wheat Crops in a European Temperature Region. Agriculture, Ecosistem and Evironment. 181: 223-230

Pelosi C, Barot S, Capowiez Y, Hedde M, Vandenbulcke F. 2014. Pesticide and Earthworms: a Review. Agronomy for Sustainable Development. 34:199-228

Suin NM. 2012. Ekologi Hewan Tanah. Bumi Aksara. Jakarta

Yulipriyanto H. 2010. Biologi Tanah dan Strategi Penanganannya. Graha IImu. Yogyakarta 
